\title{
Scaling Up of Stocking Density of Tiger Shrimp (Penaeus monodon) under Improved Farming System in Khulna Region of Bangladesh
}

\author{
M. I. Hossain ${ }^{1}$, A. M. Shahabuddin ${ }^{2,6^{*}}$, M. A. B. Bhuyain ${ }^{3}$, M. A. Mannan ${ }^{4}$, \\ M. N. D. Khan ${ }^{2}$ and R. Ahmed \\ ${ }^{1}$ Gazi Fish Culture Ltd, Koilashgong, Khulna, Bangladesh. \\ ${ }^{2}$ Graduate School of Bioresources, Mie University, Mie Prefecture, 514-8507, Japan. \\ ${ }^{3}$ Institute of Marine Sciences and Fisheries, University of Chittagong, Bangladesh. \\ ${ }^{4}$ Department of Fisheries Management, Bangladesh Agricultural University, Bangladesh. \\ ${ }^{5}$ Department of Fisheries, Ministry of Fisheries and Livestock, Dhaka, Bangladesh. \\ ${ }^{6}$ Department of Fisheries, Sher-e-Bangla Agricultural University, Dhaka-1207, Bangladesh.
}

Authors' contributions

This work was carried out in collaboration between all authors. Author MIH designed the experiment and collected the data in the field station. Author AMS also involved in designing the experiment, performed the statistical analysis and wrote the manuscript. Authors MABB,

RA and MAM managed the analyses of the study, helped in data collection. Author MNDK managed the literature searches and manuscript correction. All authors read and approved the final manuscript.

Research Article

Received 25 $5^{\text {th }}$ April 2013

Accepted 25 $5^{\text {th }}$ June 2013

Published $12^{\text {th }}$ July 2013

\section{ABSTRACT}

Aims: Scaling up of stocking density of black tiger shrimp (Penaeus monodon) under improved shrimp farming system in the Khulna region of Bangladesh.

Study Design: Completely randomized design (CRD) with three treatments each with three replicates.

Place and Duration of Study: In the farm station of Gazi fish culture Itd. at Koilashgong, Khulna, Bangladesh between March to June 2011.

Methodology: Nine ponds were selected and all ponds were prepared according to the general pond preparation system. Polymerase chain reaction (PCR) tested post larvae $\left(P L_{15}\right)$ were stocked at three different stocking densities i.e. $8 \mathrm{pcs} / \mathrm{m}^{2}(\mathrm{~T} 1), 15 \mathrm{pcs} / \mathrm{m}^{2}(\mathrm{~T} 2)$ 
and $22 \mathrm{pcs} / \mathrm{m}^{2}$ (T3). Commercial shrimp feed were supplied to all the treatments. Feed were adjusted according to the body weight gain of shrimp. Probiotics were applied in all the treatments to prevent diseases and maintain water quality parameters. Monthly water samples were collected for analysis and growth parameters were measured.

Results: Results showed that all the water quality parameters were within the optimum

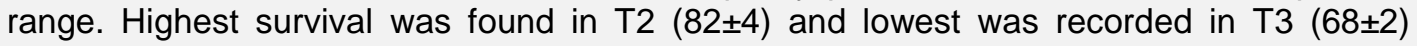
$(P<0.05)$. Harvesting size of shrimp varied from $29.0 \pm 1.53 \mathrm{~g}$ to $38.5 \pm 0.5 \mathrm{~g}$. Harvesting size was smaller in T3 than in T1 and T2 $(P<0.05)$. Stocking density of 15 and $22 \mathrm{pcs} / \mathrm{m}^{2}$ exhibited the highest production of $4635.1 \pm 128 \mathrm{~kg} / \mathrm{ha} / \mathrm{crop}$ and $4328.7 \pm 138.2 \mathrm{~kg} / \mathrm{ha} / \mathrm{crop}$ respectively whereas, T1 showed lowest $(2431.3 \pm 35.2 \mathrm{~kg} / \mathrm{ha} / \mathrm{crop})$. It was observed that two crops can be found from each pond/year. Net profit calculation showed that highest net profit was found in T2 compared to other treatments $(P>0.05)$.

Conclusion: The research showed that stocking density of tiger shrimp $15 \mathrm{pcs} / \mathrm{m}^{2}$ is the optimum density for improved shrimp farming system in Khulna region of Bangladesh.

Keywords: Stocking density; culture system; tiger shrimp; Penaeus monodon; Bangladesh.

\section{INTRODUCTION}

Shrimp farming is a century-old practice in many Asian countries. It is one of the most exportable frozen products of Bangladesh [1]. The culture of shrimp received maximum importance due to its high value in the world market as well as its unique taste; high nutritive value making it's a quick profit item in the country. Until a decade ago, this commodity was generally considered a secondary crop in traditional fish farming practices. Shrimp fry trapped in salt beds, coastal paddy fields or brackish water fishponds were allowed to grow to marketable size and harvested as secondary crop. However, in recent years when higher income are derived from the harvest of shrimp than the principal crop, many farmers have converted their rice fields, salt beds and fishponds into shrimp farms [2].

In Bangladesh the shrimp farming mostly concentrated in the southern region and about $80 \%$ of the areas are in Khulna region that covers more than 145 thousand hectares of land. Most of the culture techniques are done through extensive method where production never goes above $120 \mathrm{~kg} / \mathrm{ha} / \mathrm{year}$ [3]. In the traditional farming system, the ponds are stocked with fry either collected from the wild or concentrated through tidal water entering the ponds [4]. Subsequently yield is very low because of inefficient control of predators and competitors, full dependence on natural food, inadequate pond depth and water quality management. Some improvements of the traditional farming systems have been made in the past years. Stocking density of shrimp can be increased through better management practices. As a result, pond yield has correspondingly increased. However, expansion of the shrimp farming industry is still restricted due to the lack of suitable culture technology and disease problems in Bangladesh.

The success in the mass production of shrimp can be achieved to $4-5$ tons/ha through improved pond culture techniques, water quality management and artificial feeding. Shrimp farming has now developed into an important export-oriented food industry especially in South Asian countries. The perception of an unlimited market demand, high export price, generation of employment and increase in foreign exchange earnings may have encouraged many countries in the region rich in aquatic resources to place high emphasis on the development of the shrimp culture industry. However till now optimization of stocking density 
in shrimp farming in Bangladesh is the triggering factor for maximizing the survival rate and boost up production. Stocking density also related to the culture system and environmental condition of the agro-ecological conditions. Most of the research findings are concentrated on the extensive farming system and pond dynamics of shrimp farms in Bangladesh [5-7]. Some of the research works on stocking density and total production by Shofiquzzoha and Ahmed [8], Apud et al. [9], Islam et al. [10], Islam and Alam [11], Nuruzzaman et al. [12], were showed that in all cases the stocking density were within the $5 \mathrm{pcs} / \mathrm{m}^{2}$ and the production were not more than $760 \mathrm{~kg} / \mathrm{ha}$, that is much lower compare to the neighboring countries [3]. Information on improved farming system compare to the present conventional system with higher stocking density is still lacking. However, there is little research on the improved farming system in the farm scale. That is why the present experiment was carried out for scaling up of stocking density of black tiger shrimp ( $P$. monodon) under improved shrimp farming system in Khulna region of Bangladesh.

\section{MATERIALS AND METHODS}

The experiment was carried out in the farm station of Gazi fish culture Itd. at Koilashgong, Dakop upazilla of Khulan, Bangladesh from March to July 2011. Nine ponds were selected for three treatments with three replications. All ponds were prepared according to the general pond preparation system. Black soil of the pond was eliminated and pond bottom was allowed to sun dry. The average $\mathrm{pH}$ was calculated and required amount of lime was applied to maintain the optimum $\mathrm{pH}$. The ponds were fenced by net to prevent entering other species. PCR tested post larvae at 15 days old $\left(\mathrm{PL}_{15}\right)$ average weight $0.05 \mathrm{~g}$ were stocked in each pond maintaining three different stocking densities i.e. $8 \mathrm{pcs} / \mathrm{m}^{2}$ in Treatment 1 (T1), 15 $\mathrm{pcs} / \mathrm{m}^{2}$ in Treatment 2 (T2) and $22 \mathrm{pcs} / \mathrm{m}^{2}$ in Treatment 3 (T3). The experiment was set up according to the completely randomized design (CRD) protocol.

Ponds were filled with water by filtration with small mesh size filter net. The initial water levels in the ponds were maintained at $60 \mathrm{~cm}$ level. After filling the pond, crab net was fixed along the pond perimeter. Ponds were bleached with bleach containing $30 \%$ chlorine at the rate of $60 \mathrm{ppm}$ [13]. Inorganic fertilizers were applied weekly for producing natural food in the culture ponds at a rate of $28 \mathrm{~kg} \mathrm{~N} / \mathrm{ha} /$ week and $7 \mathrm{~kg}$ P/ha/week [14]. Different types of chemicals and minerals such as dolomite, sodamix, nutrilake and A-soil were applied to the pond in the three days interval during the pond preparation. After three weeks the ponds were ready for stocking and the seeds were acclimatized to the pond environment. After acclimatization seeds were released slowly to the ponds water.

Commercial shrimp feed were applied in all the treatments (Table 1). Blind feeding was done for first 30 days. Later the feeding was adjusted based on the check tray observation and body weight sampling. Four check trays were installed in each pond for monitoring the shrimp health conditions and feed intake. The feed ration was divided into 4 times a day as $25 \%, 20 \%, 30 \%$ and $25 \%$ in the morning at 6.00 a.m., 11.00 a.m., 6.00 p.m. and 10.00 p.m. respectively. The ingredients of the feed include Fish meal, Cod liver oil, Shrimp/prawn meal, Squid meal, Wheat flour, Binder, Soybean meal, Broken rice, Phospholipid, Cholosterol, Vitamins and Minerals, Di calcium phosphate etc. 
Table 1. Composition of commercial feed applied during the culture period

\begin{tabular}{ll}
\hline Composition & Percentage \\
\hline Moisture & 11 (maximum) \\
Crude Protein & 38 (minimum) \\
Fat & 5 (minimum) \\
Fiber & 4 (maximum) \\
\hline
\end{tabular}

Additional water exchange was not done for the first 60 days. After that $12 \mathrm{~cm}$ of water was added regularly in every 15 days interval till harvesting and water level was maintained around one meter in all the ponds. Commercial probiotics were collected from local market. Based on the water quality parameters and health conditions of shrimp, probiotics were applied in all the treatments during the culture period (Table 2). Sampling was done in the pond every week during early hours of the day with cast net for checking the healthiness and growth rates. The water quality parameters of the culture pond were regularly monitored. Monthly water sample were collected for analysis. The water level was measured by using a handmade wooden scale with $\mathrm{cm}$ marking. The water salinity of the pond was measured by using a hand refrectometer (Erma-Japan). The $\mathrm{pH}$, alkalinity, total ammonia nitrogen (TAN) of the pond water was recorded by using $\mathrm{pH}$ test kit, alkalinity kit and ammonia test kit respectively (Advance Pharma, Thailand). Water temperature was measured by using a standard centigrade thermometer. The dissolved oxygen (DO) was estimated by DO test kit (Advance Pharma, Thailand). Transparency was observed in terms of light penetration by using Secchi disc.

Economic analysis was done considering all variable costs to the expenditure and respective shrimp sales of the treatment to the gross return. One way ANOVA was done to observe the differences in growth, survival rate, production, FCR values and economic return among different treatments.

Table 2. Name of probiotics used during the experimental period

\begin{tabular}{llll}
\hline Name of probiotics & Bacterial Composition & Concentration & Doses \\
\hline Super P S & Rhodobacter sp, Rhodococcus sp & $\pm 10^{9} \mathrm{CFU} / \mathrm{ml}$ & $20 \mathrm{Lt} / \mathrm{ha}$ \\
Super Biotic & Bacillus sp & & $5 \mathrm{Kg} / \mathrm{ha}$ \\
Mutagen & Enzyme compound & $10 \mathrm{~g} / \mathrm{kg} \mathrm{Feed}$ \\
Zymetin & Enzyme compound & $5 \mathrm{~g} / \mathrm{kg} \mathrm{Feed}$ \\
Pro-w & Bacillus subtilis, Bacillus licheniformis & $5 \times 10^{10} \mathrm{CFU} / \mathrm{g}$ & $250 \mathrm{~g} / \mathrm{ha}$ \\
Pro-2 & Bacillus subtilis, Bacillus & $2 \times 10^{10} \mathrm{CFU} / \mathrm{g}$ & $10 \mathrm{~g} / \mathrm{kg} \mathrm{Feed}$ \\
& licheniformis, Bacillus pumilus & & \\
\hline
\end{tabular}

\section{RESULTS AND DISCUSSION}

Salinity was found between 10-18 ppt during the culture period. The average $\mathrm{pH}$ was fluctuated within the range of 7.7 to 9.4 in different treatments (Table 3). DO remained within the suitable limit and DO was recorded maximum $8.5 \mathrm{mg} / \mathrm{l}$ and minimum $3.5 \mathrm{mg} / \mathrm{l}$. The temperature of the water was ranged between 27 to $34^{\circ} \mathrm{C}$ during entire culture period. Transparency ranges from 25 to $55 \mathrm{~cm}$ during the culture period. Total ammonia nitrogen (TAN) was 0.1 to $0.5 \mathrm{mg} / \mathrm{l}$ in culture period. The highest was observed in the T3. Most of the time the unionized ammonia level in three treatments were between 0.002 to 0.004 . However with increasing the $\mathrm{pH}$ and temperature sometimes it was increased. The water 
quality parameter in different treatments did not show any significant difference among the treatments.

Table 3. Water quality parameters in different treatments during the experiment

\begin{tabular}{llll}
\hline Parameters & Treatment 1 (T1) & Treatment 2 (T2) & Treatment 3 (T3) \\
\hline Salinity $(\mathrm{ppt})$ & $10-17$ & $12-18$ & $11-17$ \\
$\mathrm{pH}$ & $7.8-9.2$ & $7.7-9.1$ & $7.9-9.4$ \\
Temperature $\left({ }^{\circ} \mathrm{C}\right)$ & $27-34$ & $27-34$ & $27-34$ \\
Transparency $(\mathrm{cm})$ & $26-50$ & $27-54$ & $20-35$ \\
Dissolved Oxygen $(\mathrm{mg} / \mathrm{l})$ & $3.5-8.5$ & $4.0-8.0$ & $3.5-8.5$ \\
Total ammonia Nitrogen & $0.1-0.25$ & $0.1-0.2$ & $0.1-0.5$ \\
(TAN) $(\mathrm{mg} / \mathrm{l})$ & & & \\
Un-ionized ammonia $(\mathrm{mg} / \mathrm{l})$ & $0.004-0.151$ & $0.0024-0.098$ & $0.0039-0.302$ \\
Total alkalinity (mg/l) & $120-135$ & $125-130$ & $110-130$ \\
\hline
\end{tabular}

The growth rates and production data of $P$. monodon are shown in Table 4 and 5 . Shrimps were cultured for 144 days. The harvesting size of shrimp varied from $29.0 \pm 1.5 \mathrm{~g}$ to $38.5 \pm 0.5$ g. The lowest was observed in T3 that was significantly lower than T1 and T2 $(P<0.05)$. Daily weight gain of shrimp was significantly different among treatments. Treatment 3 showed lowest value than other treatments and the value was $0.20 \pm .00 \mathrm{~g} /$ day $(P<0.05)$. The highest survival was found in T2 $(82 \pm 4)$. The survival rate was found lowest in T3 $(68 \pm 2)$ that was significantly lower than $\mathrm{T} 1$ and $\mathrm{T} 2(\mathrm{P}<0.05)$ (Table 4). The average production in different treatments showed significant difference $(P<0.05)$. Stocking density $15 \mathrm{pcs} / \mathrm{m} 2$ and $22 \mathrm{pcs} /$ $\mathrm{m}^{2}$ exhibited the highest production of $4635.1 \pm 128 \mathrm{~kg} / \mathrm{ha} / \mathrm{crop}$ and $4328.7 \pm 138.2 \mathrm{~b}$ $\mathrm{kg} / \mathrm{ha} / \mathrm{crop}$ respectively, and lowest was observed in lowest stocking density of $8 \mathrm{pcs} / \mathrm{m} 2$ (2431.3 $\pm 35.2 \mathrm{~kg} / \mathrm{ha} / \mathrm{crop})$ in T1 (Fig. 1).

Total amount of feed used in different treatments were significantly different among the treatments as the number of $P L$ was different in three treatments $(P<0.05)$. The highest amount of feed was used in T3 $(3963.7 \pm 77.3 \mathrm{~kg})$. FCR in T3 was significantly different than $\mathrm{T} 1$ and T2 $(\mathrm{P}<0.05)$. Highest FCR value was observed in T3 and the value was $1.83 \pm 0.03$. However, there was no significant difference among the FCR value between T1 and T2 (Table 4).

Table 4. Production performance of Penaeus monodon under different stocking densities

\begin{tabular}{llll}
\hline Parameters & Treatment 1 (T1) & Treatment 2 (T2) & Treatment 3 (T3) \\
\hline Stocking size $(\mathrm{g})$ & $0.05 \pm 0.0$ & $0.05 \pm 0.00$ & $0.05 \pm 0.00$ \\
Initial biomass $(\mathrm{kg})$ & 2 & 3.75 & 5.5 \\
Harvesting size $(\mathrm{g})$ & $38.5 \pm 0.5^{\mathrm{a}}$ & $37.6 \pm 0.74^{\mathrm{a}}$ & $29.0 \pm 1.53^{\mathrm{b}}$ \\
Daily weight gain $(\mathrm{g} /$ day) & $0.26 \pm .00^{\mathrm{a}}$ & $0.26 \pm .00^{\mathrm{a}}$ & $0.20 \pm .00^{\mathrm{b}}$ \\
Production $(\mathrm{kg} / \mathrm{ha} / \mathrm{crop})$ & $2431.3 \pm 35.2^{\mathrm{a}}$ & $4635.1 \pm 128.4^{\mathrm{b}}$ & $4328.7 \pm 138.2^{\mathrm{b}}$ \\
Survival & $79 \pm 2^{\mathrm{a}}$ & $82 \pm 4^{\mathrm{a}}$ & $68 \pm 2^{\mathrm{b}}$ \\
FCR & $1.433 \pm 0.03^{\mathrm{a}}$ & $1.513 \pm 0.02^{\mathrm{a}}$ & $1.833 \pm 0.03^{\mathrm{b}}$ \\
\hline
\end{tabular}


Table 5. Economic analysis of Penaeus monodon farming under different stocking densities

\begin{tabular}{llll}
\hline Parameters & Treatment 1 (T1) & Treatment 2 (T2) & Treatment 3 (T3) \\
\hline Feed used (kg) & $1741.0 \pm 21.7^{\mathrm{a}}$ & $3508.7 \pm 131.3^{\mathrm{b}}$ & $3963.7 \pm 77.3^{\mathrm{c}}$ \\
Feed cost (tk) & $144503.0 \pm 1801.3^{\mathrm{a}}$ & $291219.3 \pm 10901.6^{\mathrm{b}}$ & $328984.3 \pm 6412.4^{\mathrm{c}}$ \\
Probiotics cost (tk) & $17333.3 \pm 1453.0^{\mathrm{a}}$ & $89333.3 \pm 6984.1^{\mathrm{b}}$ & $88333.3 \pm 4409.6^{\mathrm{b}}$ \\
Chemical cost (tk) & $12333.3 \pm 1453.0^{\mathrm{a}}$ & $32666.7 \pm 1453.0^{\mathrm{b}}$ & $49333.3 \pm 3480.1^{\mathrm{c}}$ \\
Total Cost (tk) & $304169.7 \pm 4030.2^{\mathrm{a}}$ & $560719.3333 \pm 15817.9^{\mathrm{b}}$ & $631651.0 \pm 7662.5^{\mathrm{c}}$ \\
Net profit (tk) & $650535.0 \pm 16679.7^{\mathrm{a}}$ & $1242844.6 \pm 16576.4^{\mathrm{b}}$ & $707766.0 \pm 54557.7^{\mathrm{a}}$ \\
Profit percent & $213.7 \pm 7.7^{\mathrm{a}}$ & $221.8 \pm 3.5^{\mathrm{ab}}$ & $111.3 \pm 7.5^{\mathrm{c}}$ \\
\hline
\end{tabular}

The cost of feed was also significantly different among the treatments. The highest feed cost was observed in T3 (328984.3 $\pm 6412.4 \mathrm{tk}$ ) and lowest was in (144503.0 $\pm 1801.3 \mathrm{tk}$ ) (Table 5). For the prevention and control of diseases probiotics and chemicals were used in all the treatments. The cost of the probiotics in T1 was significantly different than T2 and T3 $(\mathrm{P}<0.05)$. The cost of probiotics was lowest in $\mathrm{T} 1$ than other treatments. On the other hand the costs of chemicals were significantly different between each treatment. The highest cost was observed in T3 $(49333.3 \pm 3480.1 \mathrm{tk})$ and lowest was observed in T1 (12333.3 \pm 1453.0 tk) (Fig. 2).

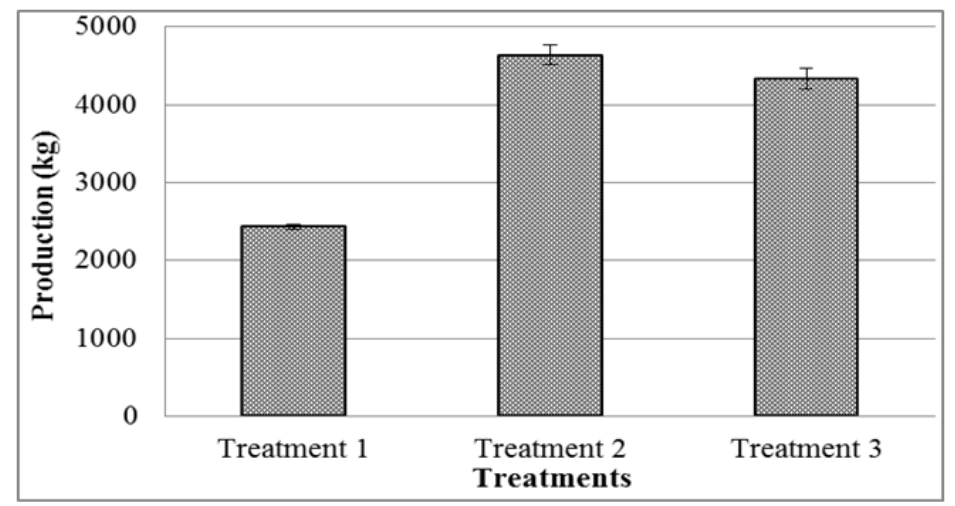

Fig. 1. Production of $P$. monodon in different treatments during the experiment

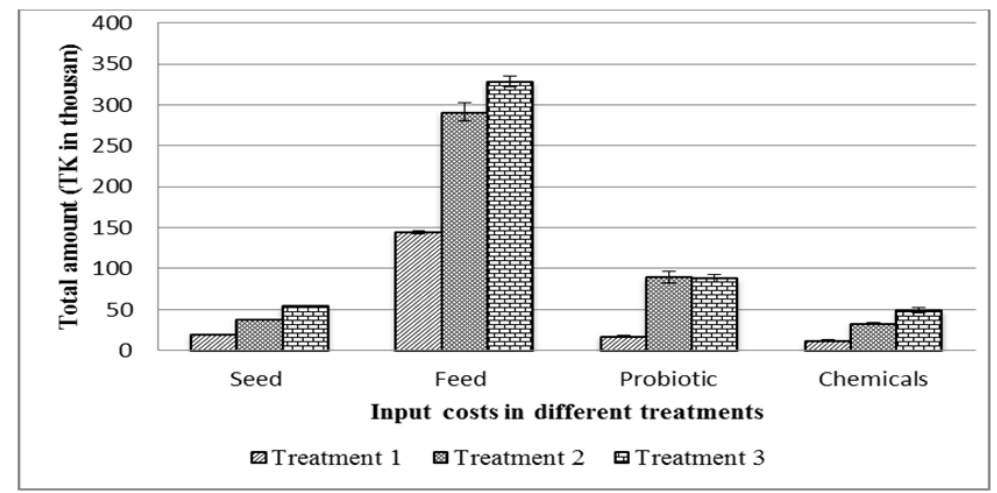

Fig. 2. Major expenses during the experimental period in different treatments 
The farming of the black tiger shrimp has been increasing in Bangladesh due to high demand and price in the international market. But there are lot of obstacles in shrimp farming to makes it as a sustainable aquaculture business. To make shrimp farming sustainable, stocking density of post larvae in a pond is determined in accordance with the production capacity of the pond and the culture system, which included the soil and water quality, food availability and seasonal variations, target production. Moreover, farmers experience is also essential. In the present study the production of $P$. monodon was found better in the stocked density of 15 and $22 \mathrm{pcs} / \mathrm{m}^{2}$, that is similar to the statements of Ramanathan et al. [15]. They also found that stocking density between $10-20 \mathrm{pcs} / \mathrm{m}^{2}$ was ideal for successful shrimp farms and for the nursery of shrimp Khan et al. [16] suggested the stocking density of 100 $\mathrm{pcs} / \mathrm{m}^{2}$.

All the common water quality parameters were within the range for shrimp. Salinity, $\mathrm{pH}$, Temperature, Dissolve oxygen were within the limit according to Boyd [17-18]. Sometimes with increasing the $\mathrm{pH}$ and temperature the unionized ammonia was increased specially in the T 3, It might be due to the large amount of feed used. In such situation proper aeration and probiotics were used to control it. Probiotics might also helpful in controlling the toxic ammonia. Feed is one of the essential inputs in shrimp production and increase profits. Feed management is very important, as feed consumption cannot be directly observed. Excess nutrients which may affect pond water quality and increase cost of farming [19]. In the present experiment the total amount of feed given to the different treatments was $1741.0 \pm 21.7 \mathrm{~kg}, 3508.7 \pm 131.3 \mathrm{~kg}, 3963.7 \pm 77.3 \mathrm{~kg}$ in T1, T2 and T3 respectively. The FCR value was higher in T3 (1.8) compare to other treatments. Lowest FCR value was found in T1 (1.4). Paul [20] reported that the average food conversion ratios of shrimp were varying 1.5 to 1.75. Cheekait [21] observed the food conversion ranges were varying from 1.50 to 1.55 when microencapsulated diets were used. Saha et al. [22] observed that the food conversion ratios of 1.31 to 1.58 in low saline ponds and 1.35 and 1.68 in high saline ponds. In the experiment the FCR value of T1 and T2 were within the recommended limit.

The survival rate was $79 \pm 2,82 \pm 4,68 \pm 2$, in the $T 1, T 2$ and T3 respectively. The lowest survival rate was found in highest stocking density and this might be due to the cannibalism, higher level of ammonia and other water quality parameters as in this treatment highest amount of feed were applied. Due to the lack of facility it was not possible to analyze the Nitrate-nitrogen and Nitritate-nitrogen. Krantz and Norris [23] stated that survival rates of 60 to $80 \%$ are to be expected for $P$. monodon under suitable rearing conditions. Reddy [24] got $76 \%$ survival during the culture of shrimp. The author suggested that $70-80 \%$ survival is possible if the idle conditions are maintained for $P$. modonon. In the present study the average body weight of the shrimps were calculated as $38.5 \pm 0.5 \mathrm{~g}, 37.6 \pm 0.74 \mathrm{~g}$ and $29.0 \pm 1.53 \mathrm{~g}$ in T1, T2 and T3 respectively. The average body weight of tiger prawn $35.2 \mathrm{~g}$ was found by Reddy [24] that is similar to the present experiment.

In normal practice of shrimp culture in south western region of Bangladesh farmers are using extensive culture system without any supplemental feed. In this experiment we used higher stocking density than the normal practice with commercial feed, probiotics and proper management system. It was found that the production of shrimp was $4635.1 \pm 128 \mathrm{~kg} / \mathrm{ha} / \mathrm{crop}$ with stocking density $15 \mathrm{pcs} / \mathrm{m}^{2}$. The production of shrimp in the stocking density of 22 $\mathrm{pcs} / \mathrm{m}^{2}$ was $4328.7 \pm 138.2 \mathrm{~kg} / \mathrm{ha} / \mathrm{crop}$ where as in the lowest stocking density $(8 \mathrm{pcs} / \mathrm{m} 2)$ it was $2431.3 \pm 35.2 \mathrm{~kg} / \mathrm{ha} / \mathrm{crop}$. But there was no significant difference among the production shrimp in T2 and T3. In T1 the harvesting size was highest and lowest was in T3. However due to the lowest stocking density in T1 the production was lowest in the treatment Treatment two showed best production performance and this might be due to the optimum 
stocking density for this improved aquaculture practice. However due to the lower survival in T3, the final production was lower the treatment. In all the treatments probiotics and chemicals were used for the prevention of diseases and maintain water quality parameters. Islam and Alam [11] reported that production of shrimp culture for 120 days with stocking density $5 \mathrm{pcs} / \mathrm{m}^{2}, 7 \mathrm{pcs} / \mathrm{m}^{2}, 9 \mathrm{pcs} / \mathrm{m}^{2}$ was $759.14 \mathrm{~kg} / \mathrm{ha}, 670.77 \mathrm{~kg} / \mathrm{ha}$ and $701.24 \mathrm{~kg} / \mathrm{ha}$ respectively. In another experiment by Apud et al. [9] showed that production of shrimp was $340 \mathrm{~kg} / \mathrm{ha}$ with stocking density 4 to $5 \mathrm{pcs} / \mathrm{m}^{2}$ for 125 days with supplemental feed and improved water exchange system. However, in these experiments the stocking densities were lower than the present experiment. None of these experiments used probiotics for prevention and control of diseases. The average production of shrimp found in the present study in all the treatments were much more higher than those reported in the above mentioned authors for the shrimp culture in the south-western region of Bangladesh. This might be due to the use of PCR testes post larvae (PL), proper management techniques, use of probiotics, control of water quality parameters and prevention of diseases in appropriate time.

Though there was no significant difference between the total production of shrimp in T2 and T3, but total cost was higher in T3 than T2. That is why the net profit was significantly higher in T2 compare to other treatments. This might be due to the higher cost of seed, feed, chemicals for the highest stocking density and lower harvesting size of shrimp in T3. This indicated that stocking density of $15 \mathrm{pcs} / \mathrm{m}^{2}$ is best suitable for improved shrimp farming system that will give better profit to the shrimp farmers as well as will increase the shrimp production in the country.

\section{CONCLUSION}

With the improvement of culture technology, management system and higher market price of shrimp, it is needed to increase production from the limited resources. Considering the improvement of shrimp culture in neighboring countries and infrastructural facilities and environmental condition in the agro-ecological conditions of the south-western region of Bangladesh, it could be concluded the stocking density of $15 \mathrm{pcs} / \mathrm{m}^{2}$ is the best stocking density for improved shrimp farming system to boost up the production of shrimp many folds than the present farming culture system. However, further research could be done on environmental stress within the prescribed stocking density.

\section{ETHICAL APPROVAL}

All authors hereby declare that "Principles of laboratory animal care" (NIH publication No. $85-23$, revised 1985) were followed, as well as specific national laws where applicable. All experiments have been examined and approved by the appropriate ethics committee.

\section{ACKNOWLEDGEMENTS}

The authors would like to express their sincere gratitude to the authority of Gazi Fish Farm Ltd. for their support to conduct the research in their shrimp farm. The authors also would like to give thanks to the entire field workers in the farm.

\section{COMPETING INTERESTS}

Authors declare that no competing interests exist. 


\section{REFERENCES}

1. Aftabuzzaman. Sustainable Environment-Friendly Aqua-culture. In: Centre for Policy Dialogue, Environmental Consequences of Export Oriented Shrimp Culture in Bangladesh, CPD Dialogue Report No. 18, Centre for Policy Dialogue, Dhaka, Bangladesh; 1998.

2. Kungvankij P. Overview of penaeid shrimp culture in Asia. In Taki Y., Primavera J.H. and Llobrera J.A. (Eds.). Proceedings of the First International Conference on the Culture of Penaeid Prawns/Shrimps, 4-7 December 1984, Iloilo City, Philippines (pp. 11-21). Iloilo City, Philippines: Aquaculture Department, Southeast Asian Fisheries Development Center; 1985.

3. Ahmed SA, Mallick DL, Ali ML and Rahman AA. Literature review on Bangladesh shrimp. individual partner report for the Project: Policy Research for Sustainable Shrimp Farming in Asia (PORESSFA), a comparative analysis of Bangladesh, India, Thailand and Vietnam with particular reference to institutional and socio-economic aspects. European Commission INCO-DEV Project PORESSFA No.IC4-2001-10042, CEMARE University of Portsmouth UK and BCAS, Dhaka, Bangladesh; 2002.

4. Ahamed F, Hossain MY, Fulandaa B, Ahmed ZF and Ohtomi J. Indiscriminate exploitation of wild prawn post larvae in the coastal region of Bangladesh: A threat to the fisheries resources, community livelihoods and biodiversity. Ocean and Coastal Management. 2012;66:56-62.

5. Islam ML, Alam MJ, Rheman S, Ahmed SU and Mazid MA. Water quality, nutrient dynamics and sediment profile in shrimp farms of the Sundarbans mangrove forest, Bangladesh. Indian Journal of Marine Sciences. 2004;33(2):170-176.

6. Wahab MA, Bergheim A, Braaten B. Water quality and partial mass budget in extensive shrimp ponds in Bangladesh. Aquaculture. 2003;218:413-423.

7. Wahab MA, Bergheim A, Braaten B, Islam MS, Rahmin MM. Observation on some of the environmental parameters of selected shrimp farms in Khulna, Bangladesh. Bangladesh Journal of Fisheries Research. 2001;5(1):75-84.

8. Shofiquzzoha AFM, Ahmed SU. Improving soil, water and productivity of gher fishery. Final Report (Contart Research Project, ARMP, IDA Credit No 2815-BD). Bangladesh Fisheries Research Institute, Mymensingh, Bangladesh; 2001.

9. Apud FD, Gonzales K and Deatras N. Survival, growth and production of Penaeus monodon fabricus at different stocking densities in earthen ponds with flow-through systems and supplemental feeding. Fish. Res. J. Philippines. 1984;6(2):1-9.

10. Islam MS, Milstein A, Wahab MA, Kamal AHM, Dewan S. Production and economic return of shrimp aquaculture in coastal ponds of different sizes and with different management regimes. Aquaculture International. 2005;13:489-500.

11. Islam ML, Alam MJ. Optimization of stocking rates of tiger shrimp under modified culture system. Journal of Bangladesh Agricultural University. 2008;6(2):341-348.

12. Nuruzzaman $M$, Anwari $B$, Shahjahan $M$, Moniruzzaman $M$. The dynamics and diversity of the shrimp farming in Bangladesh. Final Report. Fourth Fisheries Project, Shrimp and Coastal Aquaculture Component, Department of Fisheries, Bangladesh; 2001.

13. Newman SG. Effective management of WSV in Shrimp, Global aquaculture advocate; 2012.

14. Yi Y, Lin CK. A manual of fertilization and supplemental feeding strategies for smallscale Nile tilapia culture in ponds, Aquaculture and Aquatic Resources Management, Asian Institute of Technology, Thailand; 2008. 
15. Ramanathan N, Padmavathy $P$, Francis $T$, Athithian $S$, Selvaranjitham N. Manual on polyculture of tiger shrimp and carps in freshwater, Tamil Nadu Veterinary and Animal Sciences University, Fisheries College and Research Institute, Thothukudi; 2005.

16. Khan MSA, Alam MJ, Rahman F, Shah MMR. Optimization of stocking densities of Penaeus monodon post-larvae in brackish water pond. Bangladesh Journal of Zoology. 2004;32(1):101-107.

17. Boyd CE. Water quality standards: $\mathrm{pH}$. The advocate; 2001.

18. Boyd CE. Water quality management and aeration in shrimp farming. Fisheries and Allied Aquaculture, Development Series No. 2. 83 pp. Alabama Agricultural Experiment station, Auburn University, Alabana, USA; 1989.

19. Briggs MRP and Funge-Smith SJ. A nutrient budgets in intensive shrimp ponds: implications for sustainability. Aquaculture. 1998;164:117-133.

20. Paul Raj BB. Eco-friendly feed and management system for sustainable shrimp culture. Fisheries World; 1999.

21. Cheekait NG. Micro-encapsulation applications in aquaculture. Aquaculture International; 1995.

22. Saha SB, Bhattacharyya C, Choudhury A. Preliminary observations on culture of Penaeus monodon in low saline waters. Naga. 1999;22(10):30-33.

23. Krantz, GC, J Norris. Proceedings of $6^{\text {th }}$ Annual World workshop, Maricualture Society, Seattle, Washington, 27-31, January, 1975;6:48-51.

24. Reddy R. Culture of the tiger shrimp Penaeus monodon (Fabricus) in low saline waters. M.Sc., dissertation, Annamalai University; 2000.

(C) 2013 Hossain et al.; This is an Open Access article distributed under the terms of the Creative Commons Attribution License (http://creativecommons.org/licenses/by/3.0), which permits unrestricted use, distribution, and reproduction in any medium, provided the original work is properly cited.

Peer-review history:

The peer review history for this paper can be accessed here: http://www.sciencedomain.org/review-history. php?iid=236\&id=2\&aid=1620 